\title{
Kościół w świecie bez Boga
}

\section{Petr Fiala, Laboratoř sekularizace. Náboženství a politika v ne-náboženské společnosti: český př́pad, Centrum pro studium demokracie a kultury, Brno 2007, 184 s.}

Gwałtownie postępujący proces ateizacji i uznawanej jako jej naturalna konsekwencja laicyzacji czeskiego społeczeństwa budzi zainteresowanie - również na arenie międzynarodowej - politologów, religioznawców, socjologów, przedstawicieli psychologii społecznej czy reprezentantów Cultural Studies. Bywa bowiem postrzegany jako konsekwencja zachwiania (i w efekcie rozkładu) tradycyjnych i przez wieki niepodważalnych modeli tożsamościowych, czerpiących źródła z uniwersalnie (w sensie uniwersum europejskiego) podzielanej wiary w istnienie i obecność instancji najwyższej - ujmowanej w kategoriach dawcy i gwaranta absolutnych praw (ontologicznych i etycznych) rządzących funkcjonowaniem antroposfery. Zainteresowaniu temu towarzyszy dość często wyrażany niepokój, z jednej strony spowodowany narastaniem odśrodkowych czy decentralizacyjnych tendencji światopoglądowych utrudniających odnalezienie wspólnego aksjologicznego mianownika czy platformy porozumienia respektowanej przez wszystkich członków zbiorowości, budowanej na podstawie ujednoliconych i powszechnie podzielanych systemów aksjologicznych, z drugiej strony zaś - otwierający dyskusję na temat konieczności poszukiwania i ustalenia nowych płaszczyzn identyfikacyjnych.

Obawy takie znajdują swój wyraz w książce Petra Fiali, politologa, byłego rektora Uniwersytetu T. G. Masaryka w Brnie, byłego ministra szkolnictwa Republiki Czeskiej (2012-2013) oraz aktualnego przewodniczącego Obywatelskiej Partii Demokratycznej (Občanská demokratická strana; ODS), zatytułowanej: Laboratoř sekularizace. Náboženství a politika v ne-náboženské společnosti: český př́pad (Laboratorium sekularyzacji. Religia i polityka w nie-religijnym społeczeństwie: przypadek 
czeski). Książka ta, podobnie jak cały dorobek naukowy jej autora, jest w Polsce niemal całkowicie nieznana, a zatem fakt, że została wydana już niemal dekadę temu, nie powinien powstrzymywać recenzenta przed decyzją o zaprezentowaniu jej polskiemu czytelnikowi. Zamieszczone w niej przemyślenia do dziś nie straciły bowiem aktualności, a skonfrontowanie ich z najnowszymi obserwacjami (np. publicystycznymi) dotyczącymi narastania symptomów laicyzacji czeskiego społeczeństwa jeszcze silniej potwierdza zasadność zaproponowanych w Laboratorium sekularyzacji ustaleń. Sam autor przyznaje na początku rozważań, że praca ta stanowi swego rodzaju polemiczną kontynuację wydanej w latach 90. ubiegłego wieku książki Katolicismus a politika. O politické dimenzi katolicismu v postmoderní době (Brno 1995) (Katolicyzm i polityka. O politycznym wymiarze katolicyzmu w epoce postmodernistycznej) traktującej o osłabianiu się politycznej i społecznej roli Kościoła katolickiego w europejskim i, ogólniej mówiąc, globalnym, wymiarze. Decyzję o powrocie do kompleksowo przed laty omówionej problematyki autor uzasadnia potrzebą zaktualizowania wcześniejszych tez (i hipotez). Upływ czasu spowodował bowiem, że obserwacje po części wymagają doprecyzowania, po części zaś - korekty. Tym razem Fiala postanowił ograniczyć rozważania do obszaru czeskiego, nie unikając oczywiście kontekstowych nawiązań i odwołań. Jego zdaniem bowiem, a twierdzenie to stanowi zarówno punkt wyjścia, jak i centralne założenie autorskiego toku dowodzenia, „Česká republika je z hlediska religiozity či spíše ne-náboženskosti společnosti «zvláštní př́ípad», k němuž je co do širre i hloubky sekularizačních procesů těžko hledat v Evropě srovnání” (s. 9). „Szczególność” czy tytułowa „laboratoryjność" (oznaczająca swoiście rozumiany doświadczalny charakter owej sekularyzacji, traktowany oczywiście w kategoriach modelowych czy egzemplifikacyjnych, a nie w sensie świadomie zaprojektowanego eksperymentu) czeskiego przypadku polega zaś na szerzej rozpowszechnionych - w porównaniu $\mathrm{z}$ innymi społeczeństwami europejskimi - postawach ateistycznych i laickich (według ustaleń socjologicznych mowa o ok. $70 \%$ ludności).

Na podstawie obserwacji, analizy wyników badań statystycznych oraz politologicznych interpretacji autor konstatuje, że przebiegający w świecie zachodnim proces sekularyzacyjny ma charakter nieuchronny i nieodwracalny. Warunkują go bowiem przemiany tożsamościowe zapoczątkowane 
przez „filozoficzną rewolucję” oświecenia i coraz silniej uobecniającą się w XIX wieku, w wyniku rozwoju nauk ścisłych (i ich praktycznej - technologicznej - aplikacji), absolutyzację kategorii postępu postrzeganego niezwykle wąsko wyłącznie jako uznanie racjonalizmu i empiryzmu za jedyny „prawidłowy” sposób oglądu, poznawania i wyjaśniania rzeczywistości. Antropologicznym wykładnikiem tych przemian staje się prawo jednostki ludzkiej do realizacji indywidualistycznych potrzeb, konsekwencją w sferze społecznej i politycznej zaś - rozwój formacji liberalno-demokratycznych i światopoglądowego pluralizmu. Czeski „szczególny przypadek" antycypuje zatem trendy, które - w bliżej nieokreślonym horyzoncie czasowym - zdominują, w opinii Fiali, wszystkie (bez wyjątku) społeczeństwa zachodnie, skazane, jak prognozuje badacz, na pogłębianie i poszerzanie tendencji laicyzacyjnych zarówno w sensie ilościowym (zwiększający się procent osób niewierzących), jak i jakościowym (budowanie aksjologicznych podstaw ustrojów państwowych na innych niż chrześcijańskie zasadach).

Laboratorium sekularyzacji wpisuje się zatem w nurt analiz i ewaluacji, które w fenomenie rozkładu metafizycznego horyzontu upatrują źródeł transformacji tożsamościowych, owocujących przebudowaniem konstrukcji społecznej i swoistym odwróceniem lub rozchwianiem hierarchii ważności autorytetów. Inwersja ta stoi zaś u źródeł nowego i poszukującego odmiennych tradycji (lub tradycje te od początku kreującego) porządku politycznego, pomijającego w swych wytycznych i założeniach duchowe potrzeby i etyczne wymogi ludzi wierzących i respektującego przede wszystkim etyczne i ontologiczne wyobrażenia laickiej większości. Fiala we wstępie do swych rozważań jednoznacznie deklaruje ,ideologiczną neutralność" reprezentowanego w pracy autorskiego stanowiska, unikając pokusy (czy raczej: pułapki) opowiedzenia się po jednej z wyraźnie rysujących się tu stron sporu, w którym usankcjonowana wielowiekowym trwaniem tradycja zderza się ze swoistą oczywistością działania mechanizmów sekularyzacyjnych kojarzonych z kategoriami postępu i nowoczesności. Sporadycznie jednak badacz pozwala sobie na ekspresję osobistych poglądów, deklarując życzliwy stosunek do owej tradycji, motywowany nie tyle rzeczywistym przeżyciem religijnej interpretacji świata, ile przeświadczeniem, że przeżycie takie umacnia czy raczej uprawomocnia prawidłowe fukcjonowanie przestrzeni społecznej: 
Pozorný a kritický čtenář však nalezne místa, která může prohlásit za normativní. Jsou tam, kde jde vytušit, že oslabování křest’ansky podmíněných hodnotových orientací pokládám pro demokratické společnosti za horší něž jejich udržení, a dokonce že ztrátu některých obecně sdílených hodnotových představ pokládám pro demokracii za rizikovou. Tato „meta-normativnost” je záměrná a neovlivňuje analýzu ani nemá předběžný vliv na závěry, nedotýká se také kritérií pro hodnocení úspěšnosti/neúspěšnosti sledovaných aktérů (s. 24).

Życzliwość ta wypływa przede wszystkim z przekonania, że strata niepodważalnego wcześniej pola wartości, stanowiąca konsekwencję odejścia od światopoglądu religijnego, powoduje swoiste rozchwianie identyfikacyjnych fundamentów umożliwiających konsolidację wspólnoty. Za ten stan rzeczy odpowiada przede wszystkim (w skali europejskiej) równouprawnienie i wypływające stąd relatywnie bezkonfliktowe współistnienie rozmaitych ideowych i (bez)wyznaniowych projektów indywidualnych i zbiorowych, legitymizowane m.in. hasłami tolerancji czy konceptami political correctness. Rozpowszechnienie i - oficjalnie przynajmniej - proklamowana akceptacja dla tych konceptów i haseł powoduje zaś, że:

Církev už nemůže být chápána jako nositelka univerzálních hodnot proto, že se hodnotový konsens české společnosti pomalu vytrácí, že tu existuje postmoderní hodnotový pluralismus a že se postupně rozmělňuje katalog hodnot, které celá společnost považuje za nezpochybnitelné (s. 95).

W konsekwencji Kościół katolicki zaczyna odgrywać rolę jednej z grup interesów, uzurpującej sobie co prawda prawo do zajęcia dominującej pozycji w praktyce życia politycznego i społecznego, jednak w niczym niewyróżniającej się ani w zakresie strategii działania, ani w dziedzinie „atrakcyjności metafizycznej oferty”, konkurującej zarówno z propozycjami egzotycznych (zwłaszcza orientalnych) wyznań, neopoganizmu, ruchów ekologicznych czy mitologii celtyckiej, jak i z prywatnymi lub kulturowymi epifaniami (w rodzaju wykreowanego dla potrzeb filmowej fikcji jedaizmu). Choć Fiala nie odwołuje się przy okazji rozważań na temat współczesnej duchowości do analiz postmodernistycznych filozofów (np. Charlesa Taylora, autora pojęcia prywatna epifania ${ }^{1}$ ), nawiązując jedynie do teorii postmaterialistycznej zmiany paradygmatu wartości Ronalda

${ }^{1}$ Cf. Bielik-Robson 2000: 277-284. 
Ingleharta, to jednak zauważa - wyraźny dziś - renesans poszukiwań metafizycznych, dodając zarazem, że nie sprzyja on, zwłaszcza w warunkach czeskich, powrotom do „wiary zinstytucjonalizowanej”, szczególnie zaś nie pomaga katolicyzmowi w odzyskaniu jego wcześniej niekwestionowanej dominującej pozycji.

W Czechach bowiem, powszechne, zdaniem Fiali, tendencje laicyzacyjne podlegają wzmożeniu i przyśpieszeniu ze względu na historyczne uwarunkowania, które - silniej niż w innych krajach - podkopały społeczny autorytet Kościoła. Co więcej, mimo zaprojektowanego w tytule książki zakresu badawczych eksploracji sugerującego szerokie spektrum analiz dotyczących relacji wszystkich chrześcijańskich wyznań z państwowym porządkiem prawnym i administracyjnym, autor skupia uwagę na sytuacji katolicyzmu, mniejszym zainteresowaniem obdarzając inne konfesje, niezbyt szeroko, w opinii badacza, reprezentowane w czeskim społeczeństwie i obdarzone o wiele bardziej ograniczoną mocą oddziaływania w przestrzeni politycznej (s. 19). Nie zastanawia się w rezultacie nad przyczynami słabości Kościołów protestanckich, które, ze względu na trwałość pamięci zbiorowej/kulturowej, powinny niejako z natury rzeczy odgrywać istotną rolę (i rolę taką odegrały w okresie międzywojennym, przede wszystkim dzięki etycznej i filozoficznej refleksji ówczesnego prezydenta odrodzonej Czechosłowacji, Tomáša Garrique’a Masaryka) w budowaniu aksjologicznych podwalin systemu ustrojowego Republiki Czeskiej. Wspomina jedynie przy tej okazji o wpływie, jaki, zgodnie ze znanymi teoriami Maxa Webera, etyka protestancka wywarła na kształtowanie i rozwój gospodarki kapitalistycznej (s. 91-92).

Najbardziej interesujące są te fragmenty książki, w których badacz dąży do zdefiniowania przyczyn leżących u podłoża procesów sekularyzacyjnych. Podkreśla przede wszystkim, że redukowanie ich jedynie do rezultatów działania komunistycznego projektu przebudowy świadomości (tożsamości) kolektywnej wydaje się daleko idącą symplifikacją (s. 27). Sterowania kolektywną pamięcią, manipulacji faktami i ,produkcji stereotypów" (,jezuici: ksiąg czeskich niszczyciele"²) decydujących o pejoratywnym postrzeganiu roli Kościoła w dziejach nie zainicjowała wszak stalinowska ateistyczna propaganda, podobne tendencje mieszczą

\footnotetext{
${ }^{2}$ Fragment znanego epigramu Karla Havlíčka Borovskiego.
} 
się bowiem w strategii komunikacyjnej Odrodzenia Narodowego, które, rehabilitując dziedzictwo husytyzmu i przyznając porażce w bitwie pod Białą Górą (1620) status największej wspólnotowej klęski, dużą część winy za utratę niepodległości przypisało właśnie - ściśle powiązanym z austriackim zaborcą - instytucjom katolickim. Fiala, rekapitulując owe, powszechnie skądinąd znane, fakty (i ich zakorzenione w refleksji naukowej i myśleniu potocznym interpretacje), sięga zatem spojrzeniem daleko wstecz, ożywiając toczoną od XIX wieku dyskusję nad destrukcyjną (czy za destrukcyjną uważaną) rolą katolicyzmu w podtrzymywaniu czeskiej świadomości narodowej. Rekapitulacja ta pozwala mu stwierdzić, że narzucony przez socjalistyczne dyrektywy nakaz ateizacji trafił w Czechach na podatny grunt, przygotowany przez pamięć o zasługach budzicieli. Pisze w efekcie o „moralnej dewastacji”, w mniejszym stopniu spowodowanej oddziaływaniem komunistycznej propagandy, w większym zaś - świadomie w praktyce życia społecznego aplikowanym systemem zachęt i przeciwwskazań (metoda kija i marchewki), który, represjonując wszelkie przejawy zachowań religijnych (trudności z uzyskaniem pracy odpowiadającej aspiracjom czy wykształceniu, zakaz edukacji w szkołach średnich i wyższych, legislacyjne kary za posiadanie Biblii na prywatnej półce z książkami itd. ${ }^{3}$ ), nagradzał nie tyle aktywną walkę z „klerykalizmem", ile całkowite zobojętnienie na sprawy wiary i represje spotykające katolików (zarówno duchownych, jak i świeckich). Neutralność taka stała się (niechcianym raczej) spadkiem po epoce reżimowych metod kształtowania postaw (czytaj: łamania kręgosłupów), skutkującym potransformacyjną zgodą na pełną sekularyzację państwa.

Książka Fiali nie wpisuje się jednak w krąg opracowań rozpatrujących czy diagnozujących rozdroża (bezdroża?) duchowych dylematów późnej nowoczesności. Ujęcie politologiczne (nieunikające oczywiście interdy-

${ }^{3}$ Mariusz Szczygieł opowiada w książce Zrób sobie raj, że: „Domaganie się podstawowego prawa do posiadania literatury religijnej mogło być uznane w komunistycznej Czechosłowacji za chorobę psychiczną. Tak oszalał Augustin Navrátil, wierzący katolik z Moraw. (...) Napisał petycję, w której domagał się swobodnego dostępu do literatury religijnej, prawa do zakładania stowarzyszeń religijnych i zlikwidowania państwowej kontroli nad każdym księdzem. (...) Został aresztowany. Umieszczono go na zamkniętym oddziale psychiatrycznym w Kroměřížu, bo uznano, że nie odpowiada za to, co robi. Dowodem na jego chorobę psychiczną było przeciwstawienie się autorytetowi państwa” (Szczygieł 2010: 151). 
scyplinarnych wycieczek w stronę socjologii, kulturoznawstwa czy historii Kościoła, co zresztą badacz podkreśla, przyznając, że każda z tych dziedzin, potraktowana oddzielnie, dostarcza jedynie rozwiązań cząstkowych) obliguje niejako autora do skupienia uwagi na relacjach zachodzących na linii państwo (ewentualnie: społeczeństwo) - instytucje religijne, usiłujące odnaleźć dla siebie przestrzeń i narzędzia oddziaływania w świecie, który już nie gwarantuje instytucjom tym uprzywilejowanej pozycji na mocy konstytucjonalnych, prawnych czy administracyjnych aktów i rozporządzeń. Za taką właśnie instytucję, w żadnym sensie nieuprzywilejowaną i szybko tracącą autorytet wartościo- i normotwórczy, Fiala uznaje Kościół katolicki. Autor wychodzi bowiem z prostego w gruncie rzeczy i nie wymagającego głębszych uzasadnień założenia, że zsekularyzowane (w większości) społeczeństwo nie przyznaje katolicyzmowi eksponowanej (czy w ogóle: jakiejkolwiek) roli w kształtowaniu postaw etycznych, budowaniu pola wartości czy definiowaniu ideowego oblicza państwa. Innymi słowy: odbiera mu prawo do zabierania głosu w dyskursie publicznym, a wszelkie próby wkraczania w przestrzeń polityki uważa za (u)roszczenie i zamiar zajęcia niezasłużonej pozycji, skutkujące redukcją przestrzeni wolności i ograniczeniem prawa do indywidualnego wyboru drogi życiowej ${ }^{4}$.

Fiala zdaje sobie jednocześnie sprawę z tego, że Europejczyk (a zatem również Czech) nie jest w stanie całkowicie „uwolnić się” spod wpływu chrześcijańskich (czy konkretnie: katolickich) wyobrażeń. Decyduje o tym bowiem zarówno historia kultury zachodniej, jak i do dziś obecne jej ,widome znaki” w postaci zabytków architektonicznych, arcydzieł artystycznych, utworów literackich i last but not least - wytworów kultury masowej. Badacz ukazuje też, jakimi narzędziami realizacji swych celów strategicznych dysponuje we współczesnej czeskiej rzeczywistości politycznej i społecznej Kościół katolicki (system szkół, najczęściej prowadzonych przez poszczególne zakony, własne czasopisma, radio Proglas

${ }^{4} \mathrm{~W}$ czeskim systemie legislacyjnym nie do pomyślenia byłby na przykład oficjalny zakaz obrazy uczuć religijnych i wynikające stąd prawne konsekwencje ścigające przejawy bluźnierstwa, karykaturalnych ujęć postaci czy narracji biblijnych lub satyrycznych ataków na przedstawicieli duchowieństwa. Ujęcia takie (i ataki) tolerowane były w czeskiej kulturze już w pierwszej połowie XIX wieku, sankcjonowała je bowiem wysoko wówczas ceniona tradycja piśmiennictwa husyckiego. 
i kanał telewizyjny Noe), stwierdza jednak, że korzystanie z nich nie przynosi pożądanych efektów (co tłumaczyć można swoistą inercją katolickiej doktryny niezdolnej do kompromisowego podporządkowania się wymogom współczesności $i^{5}$ ) i w rezultacie proponuje zespół swoistych „narzędzi naprawczych" pozwalających mu - przynajmniej po części - odzyskać i odnaleźć stosowne miejsce wśród innych organizacji, również dążących do opanowania sfery publicznej. Bardzo życzliwe ustalenia prawne (np. ułatwiające restytucję majątkową), a nawet „własna” reprezentacja polityczna w postaci partii KDU-ČSL (Křest’anská a demokratická unie - Československá strana lidová; Unia Chrześcijańsko-Demokratyczna - Czechosłowacka Partia Ludowa), której historii i metodom funkcjonowania Fiala poświęca spore fragmenty swego opracowania, nie wystarczają bowiem i nie są w stanie pomóc Kościołowi w poszerzeniu przestrzeni skutecznego oddziaływania. „Doradzając” duchownym i katolikom świeckim sposoby wyjścia z impasu, Fiala zdaje sobie oczywiście sprawę, że większość tradycyjnych i przez wieki stosowanych przez nich metod (np. działalność misyjna) nie wytrzymuje próby czasu i że ich praktyczna aplikacja w świecie czeskiej religijnej dezynwoltury wydaje się dziś niemożliwa. $\mathrm{W}$ tej sytuacji za strategię przynoszącą pozytywne efekty autor z jednej strony uznaje rezygnację z uniwersalistycznych ambicji i ograniczenie pola manewru do wąskiej grupy wierzących, z drugiej strony zaś - wyjście poza utrwalone, instytucjonalne struktury i swoistą demokratyzację funkcjonowania. Nie ukrywa jednak, że oba te „środki zaradcze” nie mieszczą się ani w tradycji katolickiej teologii, ani, tym bardziej, w nadal niepodważalnej zhierarchizowanej organizacji życia kościelnego.

W ustaleniach Fiali, szczególnie w kontekście poszukiwania rozwiązań korzystnych dla obu (religijnej i laickiej) stron opisywanego konfliktu racji i stanowisk, zastanawiać może całkowita nieobecność odwołań do sytuacji polskiej. Autor zdaje się nie zauważać (czy nie brać pod uwagę) skali odrębności różnicujących obecność Kościoła katolickiego w sferze publicznej (ewentualnie innych Kościołów chrześcijańskich, których

${ }^{5}$ Cf. „Katolická církev tedy vcelku rezignovala na rozvíjení alternativních forem pastorace, nedokázala více využít své zkušenosti z dob komunistického útlaku a její strategie převážně spočívala na obnovováni velmi tradičních forem vnitřní organizace a vnějšího společenského působení, které ale neodpovídaly podmínkám, v nichž v české společnosti od 90. let působila" (s. 48). 
status w danej państwowej, społecznej/narodowej wspólnocie określają tradycje i historyczne umotywowania) w poszczególnych krajach postkomunistycznych, ryczałtowo traktując je jako zunifikowaną przestrzeń gwałtownie nasilających się i „przyśpieszających” procesów sekularyzacyjnych. W zamieszczonej w książce bibliografii nie figuruje ani jedno odwołanie do tekstów polskich bądź choćby opisujących sytuację Kościoła w Polsce. Nawet przywołanie medialnej popularności księdza Zbigniewa Czendlika, znanego, jak go Fiala tytułuje, „duchownego celebryty", nie obliguje autora do poinformowania czytelnika, że mowa o kapłanie polskim. Informacja taka pozwoliłaby mu zaś - choćby pobieżnie i zdawkowo - zasygnalizować odmienność i specyficzny charakter roli katolicyzmu w naszym kraju, zaprezentować zróżnicowanie tradycji historycznych (katolicyzm jako ostoja polskości vs. katolicyzm jako poplecznik germanizacyjnych wysiłków zaborcy) czy choćby skonstatować, że proces powszechnej w Europie sekularyzacji może zostać powstrzymany lub całkowicie zahamowany.

Politologiczną diagnozę Fiali można skonfrontować z obserwacjami Mariusza Szczygła, który w książce Zrób sobie raj (2010) stara się opisać czeski fenomen ,życia w świecie bez Boga", przyglądając mu się z polskiej perspektywy i opisując jego najbardziej (w opinii autora) spektakularne i symptomatyczne manifestacje. Porównanie takie umożliwia bowiem zarówno potwierdzenie czy uzupełnienie tez czeskiego badacza, jak i częściową przynajmniej polemikę z zamieszczonymi w Laboratorium sekularyzacji twierdzeniami. Spojrzenie naukowca, skoncentrowane przede wszystkim na zagadnieniach obustronnych relacji zachodzących między państwem a Kościołem, siłą rzeczy eksponuje makroprocesy życia publicznego, skupiając uwagę na ogólnych, regulujących jego funkcjonowanie zasadach. Perspektywa Szczygła - reportera i eseisty - na pierwszy plan wysuwa osobisty, prywatny i indywidualny wymiar ,przeżycia niewiary”. Wnioski jednak (pomijając odmienność dyskursu) są częściowo zbieżne: Czesi „odnaleźli się” w świecie bez Boga i w najlepszym razie przyznają religii status szacownej co prawda, lecz nikomu niemal już niepotrzebnej tradycji. Inaczej jednak niż Fiala, który dość kategorycznie narzuca czytelnikowi tezę o wyraźnie antykatolickim nastawieniu większości swego zateizowanego społeczeństwa, motywując tę niechęć historycznymi doświadczeniami leżącymi u podłoża postrzegania Kościoła jako sui generis 
„obcego wtrętu” (s. 33) rozbijającego wewnętrzną jedność narodowej wspólnoty, autor Gottlandu stara się ową niechęć zinterpretować, usprawiedliwić lub nawet podać w wątpliwość ${ }^{6}$. Do pewnego stopnia upraszczające stan rzeczywisty rozważania Szczygła ukazują w efekcie - na konkretnych przykładach popartych świadectwem cytowanych wypowiedzi - skalę zróżnicowania postaw „odrzucających” światopogląd religijny (od prostej niewiedzy, przez niechęć do podporządkowania się pochodzącym spoza wewnętrznego świata jednostki systemom normatywnym, po świadomy, co oznacza: wynikający z zanegowania przyswojonych wcześniej założeń wiary, ateizm ${ }^{7}$ ). Prezentuje zatem zauważalne w praktyce życia społecznego skutki sekularyzacji opisywane przez Fialę w ujęciu modelowym i koncentrującym uwagę na zagadnieniu metod działania struktur politycznych. Obaj autorzy jednak nie zamykają swych rozważań ostatecznymi wnioskami i nie prorokują całkowitego i nieodwracalnego zaniku europejskiego, czy choćby czeskiego chrześcijaństwa, pozostawiając mu „otwartą furtkę” na przyszłość. Jak bowiem w ostatnich słowach swej pracy konkluduje Fiala:

Každá národní společnost musí projít svou cestu sama, a to i když je součástí nadnárodních celků. Na stejné podněty, totožné tendence a podobné vlivy reagují odlišně. V těchto odlišných reakcích se vlástně skrývá i naděje: zvláštní prrípad sekularizace bude sice zřejmě standardní evropskou situaci, ale nemusel by mít ve všech zemích stejné důsledky (s. 164).

${ }^{6} \mathrm{Cf}$. „Nic jednak nie wskazuje, by wśród Czechów dominowała agresywna nienawiść do katolicyzmu. W ankiecie dla czytelników tygodnika «Týden» pod tytułem Kogo podziwiamy? (maj 2002) (...) wśród bohaterów z przeszłości bezapelacyjnie wygrał Jezus Chrystus. Ankieta nie jest reprezentatywna, ale można zaryzykować tezę. Otóż prawdopodobnie jakąś część konsumentów kultury bawi gra symbolami religijnymi - lecz ich postawa nie ma nic wspólnego z brakiem szacunku dla najważniejszych w tradycji chrześcijańskiej postaci i wartości, które ze sobą niosą. (Dlaczego dla najważniejszych? Bo głównie o takich słysze1i). Słowem, udział w literackiej czy satyrycznej grze nie wyklucza podziwu dla prawdziwej świętości” (Szczygieł 2010: 123).

${ }^{7}$ Cf. „Ciągle przecież słyszę: «Jesteśmy najbardziej zateizowanym narodem świata». Tylko jedna trzecia przyznaje się do jakiegoś wyznania. Są miasteczka bardzo religijne (na Morawach). Są miasteczka, gdzie wierzy tylko jeden mieszkaniec na dziesięciu (województwo usteckie). Dwie trzecie społeczeństwa deklaruje ateizm, ale ocenia się, że może tylko jeden procent Czechów to świadomi ateiści odrzucający Boga, o którym coś wiedzą". (Szczygieł 2010: 105-106). Co ciekawe, wśród uwarunkowań wpływających na coraz silniejsze oddziaływanie mechanizmów laicyzacyjnych Fiala nie wymienia roli systemu edukacyjnego. 
W tym wyrażeniu nadziei, osłabiającej pesymistyczny wydźwięk autorskich prognoz, upatrywać zaś należy największą wartość książki Laboratorium sekularyzacji.

Anna Gawarecka

\section{Literatura}

Bielik-Robson A., 2000, Czy duchowość ponowoczesna jest możliwa, w: A. Bielik-Robson, Inna nowoczesność. Pytania o współczesna formute duchowości, Kraków, s. 277-284.

Fiala P., 1995, Katolicismus a politika. O politické dimenzi katolicismu v postmoderní době, Brno.

Szczygieł M., 2010, Zrób sobie raj, Wołowiec. 